\title{
Identities of Creativity and Humor on Instagram Style Mimi Peri Rapunchelle
}

\author{
Briant Nor Pradhuka \\ Faculty of Social and Political Sciences \\ Sebelas Maret University \\ Surakarta, Indonesia \\ briantbanana@gmail.com
}

\begin{abstract}
This article discusses, creative and humor identities of Mimi Peri Rapunchelle in Instagram, bring pros and cons. The method used is literature review by collecting data from several international journals, national journals, books, interviews and documentation. The research found, identities of Mimi Peri Rapunchelle are bringing fans and jobs, hatters, and brand image that full of controversy.
\end{abstract}

Keywords-identity; creativity; humor; mimi peri rapunchelle; Instagram

\section{INTRODUCTION}

Digital technologies have changed the way we communicate and present ourselves [1]. Social media offer new opportunities for self-presentation, impression management, self-promotion and identity performance [1]. In Indonesia, there is a selebgram has an online identity influential and controversy. The selebgram is Mimi Peri Rapunchelle. Mimi Peri Rapunchelle has a unique online identity, which identity as her internet user's him self-presentation [2]. The online identity of Mimi Elves comes from her creativity and humor. Creativity occurs when digital devices are used for various creative activities [3], and joke was shared by many people on many social media, in the digital age, as facilitated the spreading of humor [4]. In this article will present the creative identity and humor of Mimi Elves as a further discussion.

\section{LITERATURE REVIEW}

\section{A. Identity}

In the development of the modern era, it is influential to bring about new developments and transform the forms of individualism; as the 'place' where a new conception of the individual subject and how the identity works [5]. The identity of the self consists of various basic elements, so that the identity of the self can really be an aspect that characterizes an individual person is completely different from the figure of another individual [6]. From the standpoint of social psychology self-identity is the idea of a person's image [7]. Identity is that entity which enables one to move with direction and effectiveness, to find meaningful outlets [27].

\section{B. Creativity}

Creativity is the process of creating, discovery, conceptualizing, imagining, forming, constructing, producing, producing, seeing the future, predicting trends, analyzing market needs or society [8]. Creativity is related to the production of new and useful ideas on products, practices, services or procedures [9]. Creativity requires something novelty which must contain extraordinary, spectacular, different from others, and surprises or unexpected things [10]. Creativity can exists in everyday life, such as self-expression and presentation, managing personal relationships, practical artistry, and culture participation [11]. In this case, a creative person is sometimes energetic and full of ideas. This is an individual divergent thinker, open to new experiences, persistent, and a hard worker [12].

\section{Humor}

Humor is inseparable in relation to happiness, joy, jokes, and trinkets [13]. Humor is a communicative activity, when the communicator intentionally a message to the recipient and the humor are capable of causing laughter [14]. umor have been found to correlate with mental health dimensions such as positive correlations with the positive humor styles and social competence, happiness, perceived social support, satisfaction with life, and resiliency [15].

\section{Mimi Peri Rapunchelle}

Mimi Peri Rapunchelle is the character of cyberspace, played by Ahmad Jaelani citizens of Kendari Southeast Sulawesi. To date, the instgram @mimi.peri account has more than 1 million followers. Mimi Peri Rapunchelle is a person who looks to wear unique costumes from various materials from nature, such as leaves, wood, coconut shell, newspaper, cardboard, flowers, and so forth.

\section{E. Instagram}

Instagram is an app that can be downloaded and accessible from smartphones, computers, tablets, and other hardware that support this app. In Instagram, users can enjoy the facilities in it like, share and view post photos and video, using filters, create instastory and so on. Initially the dominant Instagram used for those who have fun in taking photos from a smartphone that then share the shots in this application. These uploaded photos could be landscape photographs, family photo relatives, book collection photos, and so on [16]. 


\section{RESEARCH METHOD}

This research uses a literature review research approach as a method, which attempts to obtain information in depth from several literatures about the identity formed by Mimi Peri Rapunchelle. Sources of data in this study is secondary data that is by collecting several international journals, national journals, books, interview, and documentations associated the identity of Mimi Peri Rapunchelle. In addition, an in-depth review of Mimi Peri Rapunchelle's activities in Instagram accounts from the first post on June 10, 2018.

\section{RESUlt AND DisCUSSION}

\section{A. Result}

Mimi Peri Rapunchelle is the selebgram that actively sending her ideas and creativities on Instagram. The identity of Mimi Peri on Instagram appears as an iconic female fairy. Early on, she showed herself as a beautiful woman with a unique fashion from natural tools. Such as leaves, cooking tools, balloons, plastic, twigs, as well as various other organic and nonorganic materials. In addition, Mimi Peri often features catwalk fashion, singing, dancing, and live video on her Instagram.

Mimi Peri often appears with her drama on her Instagram. Like a drama about her love story with Korean entertainers, such as Oh Sehun, Lee Minho, and other famous actor. Mimi Peri also shows her affection to her mother "Emak Ratu". The drama made by Mimi Peri on Instagram often makes her followers become entertained, care, and even bullying it.

From her creativity and humor, Mimi Peri is trusted by several sponsors as endorsers of their products. Like endorser products of electronic, fashion, beauty, food, and others. The sponsors' products are featured by Mimi Peri in the form of photos and videos along with product descriptions, shown through her Instagram feeds and Instagram story.

Mimi Peri gets sponsorships within a few weeks, according to the sponsor's agreement. Once uploaded a photo he gets a wage of Rp. 500.000, while uploading a video she earns a wage of Rp. 1.000.000 [26]. Mimi Peri worked as this endoser she was able to help her family's economy.

As a selebgram, Mimi Peri when performing with her creativity and humor, she gets lots of praise and support for her. Such as the praise, caring, and affection expressed directly by her followers. On the other hand, the creativity Mimi Peri also brings scorn, blasphemy, and bullying from her followers. Like the unlucky sissy, the cursed, and so on.

\section{B. Discussion}

Mimi Peri Rapunchelle is an online identity in Instagram created by Ahmad Jaelani. When Ahmad Jaelani conjures up a character in cyberspace he actively communicates with other Instagram users and his followers. As in CMC theory the occurrence of communication transactions between individual from computer network [17].

One of the properties of cyberspace is liquid, so it can make individuals establish an online identity based on descriptive texts as desired [18], such as Ahmad Jaelani acting as Mimi
Peri Rapunchelle, to the fullest extent he comes up with a controversial virtual image and identity.

\section{1) Brand Image}

Brand image is a reflection of a brand held in consumer memory [19]. In this context, Mimi Peri Rapunchelle has image brand as a beauty angle and she has perpetual virginity. She also mentioned that she is Oh Sehun's wife. Mimi Peri is famous for its unique fashion. So people recognize and remember it with the condition. Mimi Peri says that her residence in Southeast Sulawesi is a heaven. These are the images portrayed by Mimi Peri as a beautiful, powerful nymph.

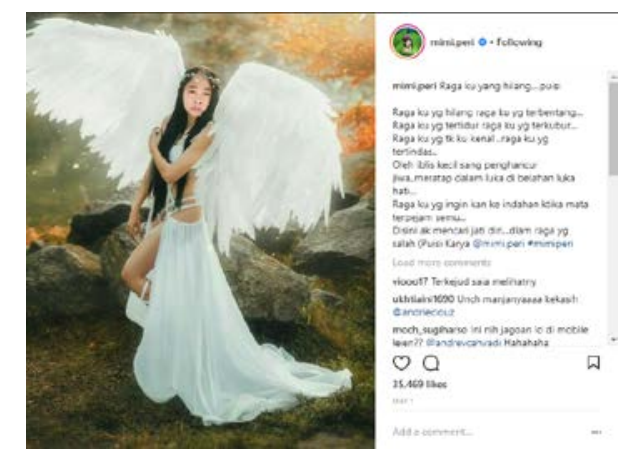

Fig. 1. One of Represent as Brand Image Mimi Peri on Her Instagram

\section{2) Creative Identity Style Mimi Peri on Instagram}

Mimi Peri Rapunchelle is a creative identity. Where, her creativity is shown by displaying iconic fashion as well as her distinctive behavior. She was uploaded her video and photos related to fashion style Mimi Peri. Fashion style Mimi Peri is original and distinctive. This is evidence of Mimi Peri having a strong perseverance. As John A. Glover, creativity and personality traits that "persons tend to become totally immersed in their work, forcing themselves to completion with a fierce determination" [10].

Fig. 2. Fashion Style Mimi Peri
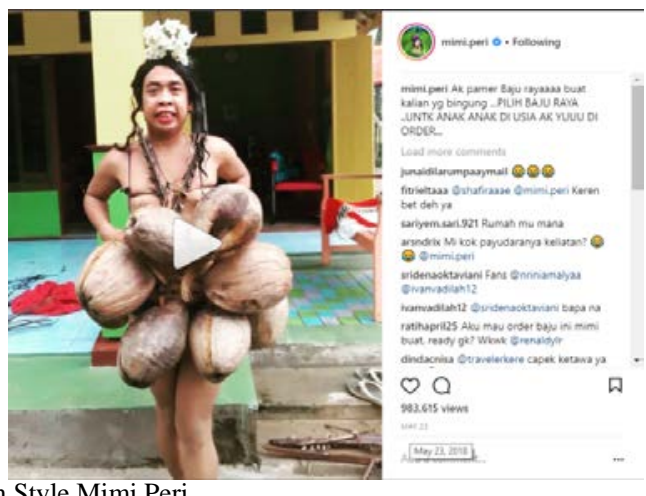

Creativity occurs in a specific space and a specific time [20]. As performed by Mimi Peri, she performed live videos and uploaded photos and videos with dance content, singing, vent, and dramas performed with typical fairy-tale. In several moments and occasions, Mimi Peri also appears with true identity as Ahmad Zailani. It is this creative identity that makes the Instagram user's enthusiasm glance at it. 


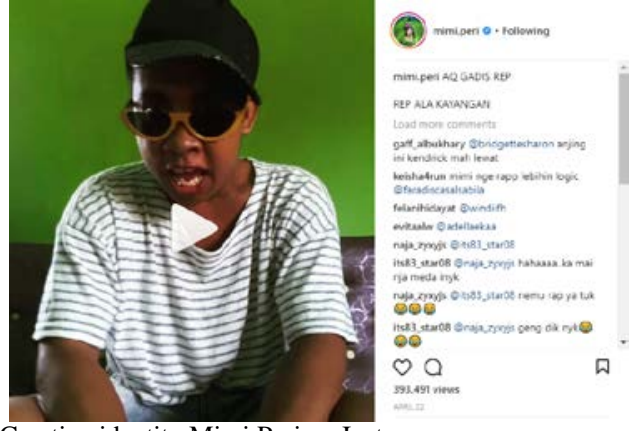

Fig. 3. RAP as Creative identity Mimi Peri on Instagram

Creative ideas are not just new and unexpected, but are also successful in finding solutions that are useful, efficient and valuable [21]. The identity displayed by Mimi Peri on Instagram includes a new, original, and unexpected identity. This is evidenced by his acknowledgment as a angle of heaven. Where she as a fairy, Mimi Peri has a high imagination about where she lives, the language, style, behavior, and recognition that always appear unexpected. Like the disclosure of virginity, marriage with famous figures. Mimi Peri appreciates as a form of creative identity.

\section{3) Humor Identity Style Mimi Peri on Instagram}

Humor is a multi-faceted phenomenon that is considered to be funny and produce laughter or a smile [22]. Like the identity of Mimi Peri's humor on her Instagram, she creates photo and video content that gives rise to laughter for his followers. As her imaginary dramas are often uploaded in some posts raises responses and laughter comments to his followers.

In addition to drama that is uploaded on Instagram feednya, Mimi Peri also often do live video Instagram with her followers. Mimi Peri doing live video with her followers, in live video Instagram it makes a lot of happiness and laughter when they talk, because there are limitations of language understanding that makes them difficult to understand each other. Humor plays an important role, because it brings individuals closer together, it makes us feel happy, and it makes us avoid argument [23].

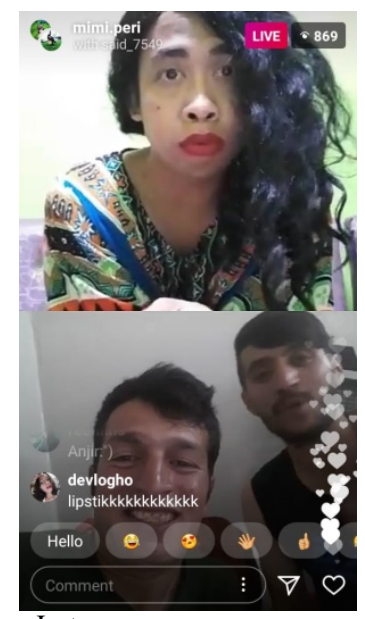

Fig. 4. Mimi Peri was live video with fans on Instagram

\section{4) Pros and Cons}

Shown as a selebgram, Mimi Peri Rapunchelle often bring up the pros and cons. With her identities of creative and humor as a angle, it often brings controversy. On the one hand, she with brand image was believed to be an endorser, on the other hand she is often in gets bullying.

Mimi Peri has many followers and fans on her Instagram. This makes itself as one of the active programming work. One of the advantages, Mimi Peri was trusted by sponsors to become endorser. Cause, celebrity endorsements have a powerful influence on consumer behavior [24].

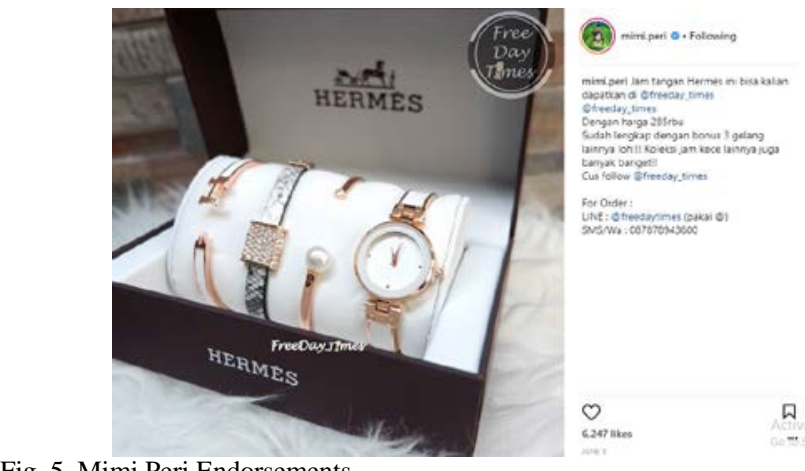

Fig. 5. Mimi Peri Endorsements

Mimi Peri has many followers and fans on her Instagram. This makes itself as one of the active programming work. One of the advantages, Mimi Peri was trusted by sponsors to become endorser. Cause, celebrity endorsements have a powerful influence on consumer behavior [24]

Brand image of Mimi Peri also brings hatters and controversy. From the displayed identity it brings a disadvantage to some Instagram users. Finally, Mimi Peri becomes a victim of cyberbullying. Cyberbullying is a condemnation and cruelty of Mimi Fairy Rapunchelle's behavior on Instagram. Cyberbullying is an activity undertaken in social media by abusing technological functions, its purpose is to humiliate, torture, make fun of, or threaten [25].
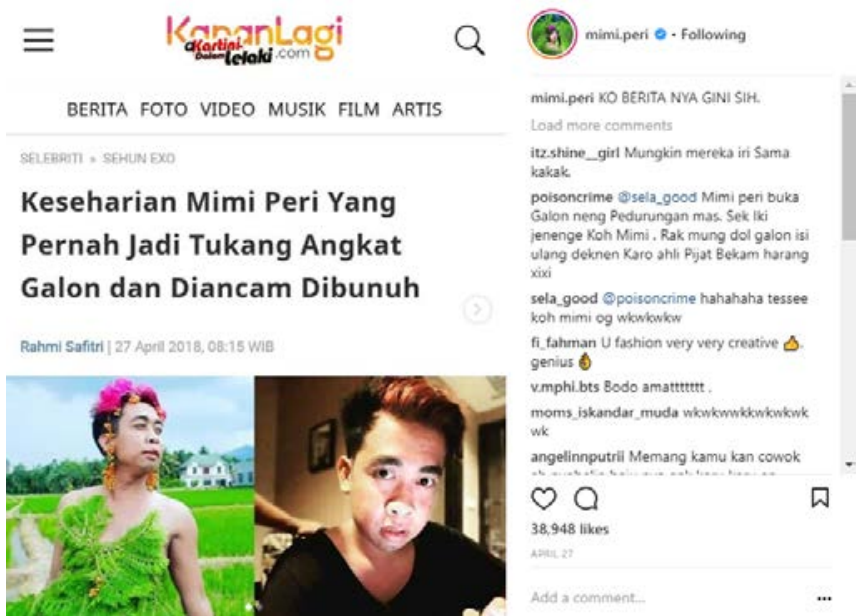

Fig. 6. Threat to Mimi Peri 


\section{CONCLUSION}

Mimi Peri Raphunchelle has a controversial online identity. Where, here identity brings pros and cons to her life. The online identity of Mimi Peri is creative identity and humor identity, both of which are interrelated and connected. Creative identity makes Mimi Peri become famous and iconic as it is today. While the identity of Mimi Elves humor makes him have many fans and hatters. Although the identity of Mimi Peri became controversial, the creativity and humor of Mimi Peri became one of the new identity phenomena that shifted the minds of the people in raising their identity in cyberspace.

\section{REFERENCES}

[1] L. Maria-Jose, "Constructing Academic Identities Online: Identity Performance in Research Group Blogs Written by Multilingual Scholars,” J. of Engl. for Acad. Purp., pp. 24-39, 2018.

[2] Y. Zhou-Min, "Exploring Chinese College Student's Construction of Online Identity on The Sina Microblog,” Disc., Cont. \& Med., pp. 1-9, 2018.

[3] R. Maria Lee and T. Tsung Chen, "Digital Creativity: Research Themes and Framework," Elsevier, pp. 1-8, 2014.

[4] G. Hirsch, "Humor Appreciation in The Digital Era," Elsevier, 13 July 2017, pp. 123-140.

[5] S. Hall, The Question of Cultural Identity, Oxford: Blackwell, 1996, pp. 596-636.

[6] Purwadi, "Proses Pembentukan Identitas Remaja [Adolescent Identity's Establishment Process],” Indo. Psychol. J., vol. 1 no.1, pp. 43-52, January 2004.

[7] A. Marwing and N. Ilman, "Identitas Diri Remaja Pengguna Game Online: Point Blank Studi Fenomenologi pada Remaja Kota Masamba [Identity of Online Gamer Adolescents: Point Blank Phenomenology Study on Adolescents of Masamba City]," National Conference on Information Technology Applications (SNATI) Yogyakarta, Jun. 21, 2014, pp. 42-47.

[8] F. Chen, Be Creative: Menjadi Orang Kreatif [Be Creative: Becoming a Creative Person], Jakarta: Prenadamedia Group, 2016, pp 5-14.

[9] M. Sigala and K. Chalkiti, "Knowledge Management, Social Media and Employee Creativity,” Elsevier, Int. J. of Hospital. Manage., pp. 44-58, 2014.

[10] A. J. Glover, Becoming a More Creative Person, Englewood Cilffs, New Jersey: Prentice-Hall, 1980, pp. 6-31.

[11] Z. Ivcevic and D. J. Mayer, “Creative Types and Personality,” Baywood Publishing Co, vol. 26 (1-2), pp. 65-86, 2006-2007.
[12] H. Kanematsu and D. M. Barry, "Theory of Creativity," Springer International Publishing Switzerland, pp. 9-13, 2016.

[13] D. Rahmanadji, "History, Theory, Types, and Humor functions," Lang. and Art J., Malang State University, vol 35, no. 2, pp. 213-221, 2007.

[14] W. Stephen Littlejohn and A. Karen Foss, Encyclopedia of Communication Theory, USA: Sage Publications, 2009, pp. 480-483.

[15] J. Aitken Schermer, A. Rod Martin, G. Nicholas Martin, T. Michael Lynskey, J. Timothy Trull and A. Philip Vernon, "Humor Styles and Borderline Personality,” Person. and Indiv. Differ., pp. 158-161, 2015.

[16] Agustina, "Analisis Penggunaan Media Sosial Instagram terhadap Sikap Konsumerisme Remaja di SMA Negeri 3 Samarinda [Analysis of the Uasge of Social Media of Instagram towards Adolescent's Consumerism in State Senior High School 3 Samarinda],” Ejournal Communication, pp. 410-420, 2016.

[17] E. Griffin, A First Look At Communication Theory, 8th ed., New York: Mc Graw Hill, 2012, pp. 138-151.

[18] E. Faranzia, Y. A. Piliang and A. I. Saidi, "Identity Representation Through Visual Communication Palanta Urang Awak Minangkabau," Panggung, vol. 25, no. 4, pp. 379-390, December 2015.

[19] J. Lahap, N. S. Ramli, N. M. Said, S. M. Radzi, and R. A. Zain, “A Study of Brand Image towards Customer's Satisfaction in the Malaysian Hotel Industry,” Procedia, Soc. Behav. Sci., vol. 224, pp. 149-157, 2016.

[20] Z. Ivcevic, "Creativity Map: Toward the Next Generation of Theories of Creativity,” American Psychol. Assoc., vol. 3, no. 1, pp. 17-21, 2009

[21] V. Georgi, Georgiev, and D. Danko Georgiev, "Enhancing User Creativity: Semantic Measures for Idea Generation,” Knoledge-Based Syst., 10 March 2018, pp. 1-66.

[22] R. Falanga, M. Elvira De Caroli, and E. Sagone, "Humor Styles, SelfsEfficacy and Prosocial Tendencies in Middle Adolescents," Procedia Soc. Behav., pp. 214-218, 2014.

[23] W. Ching-Lin, L. Hsin-Yi, and C. Hsueh-Chih, "Gender Differences in Humour Styles of Young Adolescents: Empathy as A Mediator," Elsevier, pp. 139-143, May 14, 2016.

[24] S. Kim, J. Young Choe, and F. James Petrick, “The effect of Celebrity on Brand Awareness, Perceived Quality, Brand Image, Brand Loyalty, and Destination Attachment to A Literary Festival," Elsevier, J. of Destin. Market. \& Manage., pp. 1-10, March 25, 2018.

[25] D. Satalina, "Kecenderungan Perilaku Cyberbullying Ditinjau Dari Tipe Kepribadian Ekstrovert dan Introvert [Cyberbullying Behavioral Tendencies Reviewed from Extrovert and Introvert Personality Type]," Scient. J. of Psychol. Appl. (JIPT), vol. 2, no. 2, pp. 294-310, January 2014.

[26] F. Noviandi, "Mimi Peri, Selebgram yang Pernah Jadi Kuli Bangunan [Mimi Peri, a Celebgram Who Once a Construction Laborers]," Liputan6.com, 15 October 2017.

[27] J. Kroger, "Identity Development Through Adulthood: The Move Toward “Wholeness”," Oxford Handbooks Online, March 2014, pp. 112 . 